\title{
Welcome Intrusions: Capturing the Unexpected in Translators' Prefaces to Dante's Divine Comedy
}

\section{Marella Feltrin-Morris}

\begin{abstract}
As part of an ongoing research project, this essay examines a number of translators' prefaces to Dante's Divine Comedy, summarizing recurring patterns and then focusing on deviations from the norm. The majority of these prefaces tend to follow a script, particularly in the case of retranslations of classical texts, which require an acknowledgment of past translations, a homage to the authority of the source text and a display of the translator's expertise. However, occasional detours from the predictable constellation of themes deserve closer scrutiny, since they give a more authentic voice to the individuals who engaged with the text in its deepest form, not merely within the confines of a prescriptive formula, but expanding the potential of this unique space towards new avenues of discovery.
\end{abstract}

Keywords: literary translation; translator's prefaces; Divine Comedy; retranslation; Dante

Résumé : Dans cet article, qui fait partie d'un projet de recherche en cours, nous examinons plusieurs préfaces de traducteurs de la Divine comédie de Dantes et résumons les modèles récurrents pour ensuite nous intéresser à ceux qui s'écartent de la norme. La majorité de ces préfaces suivent une même écriture qui implique une connaissance des traductions antérieures; nous voyons ici un hommage à l'autorité du texte source et une démonstration de l'expertise du traducteur. II est cependant intéressant d'examiner de plus près les écarts occasionnels par rapport à la pléiade probable de thèmes puisqu'ils donnent une voix plus authentique à ceux qui se sont consacrés au texte dans sa forme la plus profonde, et pas seulement dans les limites d'une formule prescriptive, tout en ouvrant le potentiel de ces espaces nouveaux de découvertes.

Mots clés : traduction littéraire; préfaces de traducteur; Divine comédie; retraduction; Dante

Resumo: Partindo de um projeto de pesquisa em andamento, este ensaio examina diversos prefácios de tradutores d'A Divina Comédia, de Dante, resumindo tendências recorrentes e focalizando, então, desvios da norma. A maioria desses prefácios tende a seguir um roteiro, especialmente no caso de retraduções de textos clássicos, que solicitam um reconhecimento de traduções anteriores, uma deferência à autoridade do texto original e uma demonstração da competência do tradutor. Entretanto, desvios pontuais da constelação previsível de temas merecem exame mais detido, uma vez que oferecem uma voz mais autêntica dos indivíduos que se engajam com o texto em sua forma mais profunda, não se restringindo às fronteiras de uma fórmula prescritiva, mas expandindo o potencial desse espaço singular, rumo a novas vias de descoberta.

Palavras-chave: tradução literária; prefácios de tradutor; A Divina Comédia; retradução; Dante

Resumen: Como parte de un proyecto de investigación en curso, este ensayo estudia varios prefacios de traductores de la Divina comedia de Dante, haciendo un resumen de los patrones recurrentes para luego enfocarse en las desviaciones de lo estándar. En su mayoría, los prefacios de traducción tienden a seguir una especie de guión, especialmente en el caso de la retraducción de textos clásicos, que exige un reconocimiento a las traducciones anteriores, un tributo a la autoridad del texto fuente y una demonstración de la pericia del traductor. Sin embargo, los desvíos ocasionales de la predecible constelación de temas merecen un escrutinio más riguroso, en tanto estos dotan de una voz más auténtica a aquellas personas que se han relacionado con el texto de la manera más profunda. Estos cruzan los confines de la fórmula prescriptiva y así logran expandir el potencial de este singular espacio discursivo hacia nuevas rutas de descubrimiento.

Palabras clave: traducción literaria; prefacios de traductores; Divina comedia; retraducción; Dante

Tusaaji: A Translation Review. Vol. 6, No.6. 2018. pp. 1-10 
This essay is part of an ongoing project focusing on the structure of translators' prefaces and on their potential as objects of inquiry and as spaces where the translator's own voice emerges. All too frequently missing from translated texts and, when included, rarely taken into consideration even by attentive readers (who tend to regard them merely as somewhat pedantic versions of itemized bills to be compared to tangible results), translators' prefaces are actually endowed with a much greater potential, often underestimated by translators themselves. Aside from giving visibility to the figure of the translator or shedding light on the challenges and strategies deployed in a particular translation project, they also reveal-by means of seemingly unrelated fragments of information such as autobiographical asides, spontaneous detours from the text, musings on the nature and role of translation, or connections with current events-the indissoluble ties between the translated text and the spiritual, geographical, historical, socio-political and ethical space occupied by the translator.

This research is positioned as a contribution to the burgeoning field of paratextual research within the realm of translation studies. It might therefore be useful to pause for a reflection on the scholars who have previously concentrated specifically on the topic of translators' prefaces, in order to gain a better understanding of the methodologies and directions undertaken so far and of the extent to which the perspective offered in this paper may complement what has already been accomplished. In 1995, in "Translators' Prefaces-A Key to the Translation?", Ritva Hartama-Heinonen drew from a body of prefaces written by Finnish translators for fictional and non-fictional works of all genres, praising them as useful tools to assess the quality of a translation. In 2005, in "Translators' Prefaces in Canadian Literary Texts", Christine Famula focused on the different functions of translators' prefaces written by anglophone translators for Québécois or FrenchCanadian books that covered disparate genres, and a similar approach was taken in 2009, in "Translators' Prefaces as Documentary Sources for Translation Studies" by Rodica Dimitriu, who used a very heterogeneous corpus that included prefaces written in a variety of languages by translators of different nationalities. Function, again, was the focus of Ellen McRae's essay "The Role of Translators' Prefaces to Contemporary Literary Translations into English" (2010), which concentrates on prefaces to English translations published between 1945 and 2005 of major works of world literature in order to underscore, echoing Peter Newmark, the pivotal role of translators' prefaces in drawing translators and their craft out of their anonymity. In comparison, the body of work considered by Lütfiye Oktar and Neslihan Kansu-Yetkiner is much narrower, as they use just two prefaces to Turkish translations of $\mathrm{D}$. H. Lawrence to observe the transformations in the socio-cultural, political and sexual climate of the target culture in their 2012 essay, "Different Times, Different Themes in Lady Chatterley's Lover: A Diachronic Critical Discourse Analysis of Translator's Prefaces".

I also chose to circumscribe the range of samples examined for this project, limiting it to the translator's prefaces to the English version of a single work: Dante's entire Divine Comedy or of individual cantiche. However, given the number of ambitious attempts made since 1782 to translate Dante's masterpiece into English, I was still able to peruse close to a hundred prefaces. Furthermore, while several of the researchers I cited above (as well as Gérard Genette in his influential Paratexts: Thresholds of Interpretation) extol the 
value of translator's prefaces on the basis of their function, that is, for what they do, this essay intentionally resists that approach and, inspired in part by Outi Paloposki's "The Translator's Footprints" (2010) and Carmen Toledano Buendía's "Listening to the Voice of the Translator: A Description of Translator's Notes as Paratextual Elements" (2013), delves instead into what these prefaces are and what they could be beyond the formal limits set for this genre.

On a surface level, translator's prefaces bear many similarities, and this is even truer in the case of re-translations of "classic" works, since the translator must reckon with: a) the popularity of the canonical text and the position it occupies in the target culture; b) the existing critical apparatus and the past translations of the work, which must be acknowledged before daring to produce yet another version, the value of which is considered to be ideally equal to, if not higher than, that of its predecessors; and c) the widespread and still unshakeable faith in the primacy of the source text, which makes translation merely the lesser evil, and which demands that at least a portion of the preface be devoted to self-deprecation, accompanied by insistent avowals of fidelity. These factors undeniably play a large role in predetermining the shape and content of the preface, greatly reducing any deviations from the norm and essentially doubling the invisibility effect. However, while in the translation itself invisibility or a certain degree of disguise-if pursued at all-is a strategy consciously and even creatively adopted by the translator, achieving invisibility in a translator's preface for the sake of real or presumed obligations dictated by the genre seems to obliterate the very purpose of the preface, which is to make the translator's presence manifest, unique, and essential to a more thorough understanding of the text at hand.

The first phase of my examination of prefaces to translations of Dante's Divine Comedy, which I discussed in a recent article, "Persuasive Spaces: Translators' Prefaces to the Divine Comedy", dealt precisely with the "usual suspects"-the statements and leitmotifs one would expect to find in the translator's preface to a classic text, such as the acknowledgement of past translations, which is typically benevolent even when it points out their shortcomings. The occasional jabs at one's predecessors, however, are worth lingering on as they reveal the translator's hardly-disguised ambition to be the one to rise, hand in hand with Dante, to the empyrean of eternal fame. One example is Odoardo Volpi (pseudonym of Edward Shannon), who translated the Commedia in 1836 and who, having to contend with only a handful of precedents, can aim his venom quite accurately without having to scatter it among too many competitors:

The late Mr. Hayley paraphrased the first three cantos of the Hell; and these are, perhaps, almost the only endurable things which he has written:- the list of proper names, however, in the fourth, fortunately frightened him, or we should probably have had a Dante de sa façon. A Mr. Boyd also kindly offered to the English public a wordy paraphrase of that author, in a stanza of his own invention. There is, however, in his attempt, so heavy a preponderance of Mr. Boyd that the bard of the Inferno sunk with him to a depth seemingly as great as that which he had described, and was again in the company of the damned: yet I doubt whether those attempts would not be as attractive, to most readers, as the far more accurate but rhymeless 
version of Mr. Cary. Indeed, I understand that this latter is, by many persons, considered to be inferior to its unwieldy rival, although it has had a much larger circulation. (Volpi viii-ix)

Immediately visible in Volpi's polemic is the accusation of infidelity, to the point that he calls Hayley's work a "paraphrase" and heaves a sigh of relief at the fact that Hayley limited his violation of Dante to only three cantos. The insinuation that the reason why Hayley abandoned the task was because of a daunting list of names in Canto IV is also a gratuitous attack on Volpi's part, since the list is actually quite modest and made up of very well-known figures such as Socrates, Plato and other major philosophers. Therefore, aside from possible rhyming issues, the translation of these proper nouns would not have constituted a particular problem. The malicious suggestion, of course, is that Hayley found himself clueless before these names, and so what Volpi is calling into question is not only Hayley's ability as a translator, but the breadth of his general knowledge as well. The reality might instead be closer to the interpretation offered by Dante scholar Paget Toynbee, who argued that "Hayley's attempt, which is by no means without merit, met with no encouragement, and he consequently abandoned a half-formed project of translating the whole of the poem" (qtd. in Friederich 227). It is also worth noting how Volpi makes faux-classy use of French as he paints the terrifying prospect of being subjected to a Dante à la Hayley, had the latter persisted in his wretched endeavour. Volpi unleashes no less sarcasm against Boyd's translation, which he regards as being, for Dante, the equivalent of another descent into hell. Again, as a proponent of literal fidelity, Volpi condemns Boyd's version for containing too much Boyd and not enough Dante, while he seems mildly appreciative of Cary's plain, rhymeless translation and somewhat disparaging of the public's preference for Boyd's.

Slier, but almost as biting, is J. C. Peabody, who translated Dante's Inferno some twenty years after Volpi, and who in turn dons the snow-white robe of fidelity as he lashes out at more creative translations:

While I disclaim all intention of disputing the palm as a poet or scholar with the least of those who have walked with Dante before me, yet by such labor and plodding as their genius would not allow them to descend to, have I made a more literal, and perhaps, therefore, a better translation than they all. I mean not to cavil at my fellow laborers; they tell the story better than I tell it-better perhaps than Dante tells it himself. I only aim to 'tell the tale as 'twas told to me.' The very looseness of other translators gives them room to soar to the utmost bounds of our language, while I am cramped and confined by my fidelity to the original. (Peabody vii)

It becomes increasingly evident that the weapon of choice of those who champion literalness is an ad hominem attack carried out by accusing the more "creative" translators of suffering from delusions of grandeur, and of choosing the easier path of self-expression instead of respecting the rules, however restrictive they may be, established by the source text. Curiously enough, it is in their professed humility and subservience to the source text that translators such as Peabody express their visibility, even to the point of defying

Tusaaji: A Translation Review. Vol. 6, No.6. 2018. pp. 1-10 
readers who are more partial towards versions friendlier to the ear but less so to literal meaning. Conversely, translators with a more poetic penchant play down their interventions in the text, and when they address them it is typically to justify them for the sake of fidelity to other aspects (e.g. sound, tone, effect), but they know better than to challenge their literal adversaries on the grounds of self-expression.

Even when translators refrain from levelling caustic sideswipes at their predecessors, they may still, intentionally or inadvertently, reveal an antagonistic tension in their word choice. In 1918, Courtney Langdon, while leaving subtle irony aside, explicitly portrays his effort in terms that call to mind a competition, employing the term "rival" as Volpi, too, had done over eighty years earlier:

The present translation, which is the result of over twenty years' work with large classes in 'Dante in English' at Brown University, was undertaken and continued with the object of meeting a need, which did not seem adequately met by the well known translations of Cary, Longfellow, Norton, or others more recent; it, therefore, frankly aimed at being in every possible way an improvement on its rivals old and new. (Langdon vii)

More recent translations display greater cautiousness, as the utopia of creating the ultimate, unrivalled version of the Commedia gives way to a less presumptuous desire to at least partake in the eternity of Dante's work. More often than not, contemporary translators of Dante openly declare their indebtedness to past translations and even the extent to which they helped themselves to the buffet of available options, especially when their own endeavour was not supported by a competent knowledge of the original, as Ciaran Carson, who translated the Inferno in 2002:

I was almost completely unfamiliar with the Italian language, let alone Dante's Italian, when I began reading the Inferno. My primary source was the Temple Classics Parallel text (J.M. Dent, 1900, reprinted 1932), ${ }^{1}$ and my translation owes much to it. Some phrases and rhymes have been adapted, adopted or stolen from other translations, including those of Dorothy L. Sayers, Tom Phillips, Mark Musa, Warwick Chipman, Robert M. Durling, and Robert and Jean Hollander. I trust these will be seen not as mere plagiarisms, but as homages (Carson ix- $x$ ).

Undoubtedly aware that, with the increasing number of online tools being developed for the consultation and study of Dante's works, ${ }^{2}$ any borrowings would be promptly detected, Carson plays it safe and confesses his "sins" but justifies them as tributes. Thus, the use of older translations, especially if well known and respected, is treated like a cameo in a

\footnotetext{
1 The Temple Classics Parallel text, edited by Philip Wicksteed and Hermann Oelsner, was widely circulated between 1899 and 1901, and used, among others, by Pound, Eliot, Auden, MacNeice, and Sayers (Havely 293).

${ }^{2}$ A few examples are the Princeton Dante Project, the Dartmouth Dante Project, and Digital Dante, all of which provide easily-accessible commentaries to the Commedia including different translations into English.
}

Tusaaji: A Translation Review. Vol. 6, No.6. 2018. pp. 1-10 
film, and addressing it in the translator's preface serves to give more credibility and authority to the new version being proposed.

Other recurring and predictable themes in these prefaces are those of fidelity (in its manifold shapes-to the content, the style, the sound, or the spirit of the poem); of form (with the never-ending debate of whether Dante should be translated in prose or in verse, and if in verse, in what type of verse); of the purpose that guided each choice; of the impossibility of translating Dante, or in the very least of the enormous loss that any translation of his poem entails. There is nothing new in the themes themselves, but a closer look at how they are handled reveals some intrusions, which are particularly welcome precisely because they signal a different take, a personal twist, a refreshingly rebellious stance with regard not necessarily to the source text itself (since a rebellious translation may be interesting as a statement but its subversiveness does not automatically make it worthy of praise), but to the genre of translator's prefaces, which as a result may see an increase in its rhetorical and creative potential.

For instance, in the preface to his 1966 translation of the Commedia, the writer and music critic Louis Biancolli candidly admits: "While I have tried to be as faithful as possible to what Dante says, I have also tried to keep moving" (Biancolli 1966), thus revealing his predilection for a smooth, flowing rhythm that may or may not be mirroring that of the source text. The novelty of statements like this one is not so much that it exposes the limits of literal translation (for instance, in 1949, in the preface to her own translation of the Inferno, Dorothy Sayers had stated: "Attempts at direct imitation of the packed syllables and indeterminate beat of the Italian are apt to result in a cramped and waddling line, suggestive of a person walking in thin tight shoes over cobble-stones," Sayers 59), but that it makes it clear that certain objectives (such as, in Biancolli's case, that of ironing out any creases that might slow down the reading or recitation of the piece) can and should be pursued unhesitatingly, regardless of the "sacred" reputation of the source text. However, such bold declarations are almost invariably followed by retractions, and indeed Biancolli hastens to clarify: "The English translation facing the Italian text is offered in a spirit of humility with the hope shared by all translators who have accepted the challenge of Dante-the hope that those reading the English who know some Italian but no Dante may be emboldened to face the poet in his own language" (Biancolli). Of course, the "spirit of humility" in the choice of a parallel text format may well disguise its opposite, that is, the swagger of placing one's translation on the same level-literallyas Dante's text. Still, the paradox of translation emerges quite clearly here: the perfect translation is one that leads the reader to need no translation at all.

On the whole, it is true that deviations from the norm are hard to come by within the pre-packaged subjects that ordinarily make up translators' prefaces. In order to catch a glimpse of the unexpected, one that would reveal the spirit (and not just the task) of the translator, and that would illuminate the complex chemistry between a text and its most intimate reader, it is usually more fruitful to examine the translators' personal musings, when they are generous enough to include them. John Carlyle, who translated the Inferno into prose in 1849 , vividly describes his emotion, after studying the Divine Comedy for the first time while in Italy in 1831, in hearing Italians from various social classes recite the most memorable lines by heart:

Tusaaji: A Translation Review. Vol. 6, No.6. 2018. pp. 1-10 
During the seven years which followed, I often studied it again, at leisure hours, along with the other works of Dante; and got intimately acquainted with various Italians of different ranks, who, without making any pretensions to literature, or troubling themselves with conflicting commentaries, knew all the best passages, and would recite them in a plain, sober, quiet tone-now rapid, now slow, but always with real warmth-like people who felt the meaning, and were sure of its effect. (Carlyle $v$ )

If Carlyle's portrayal comes off as somewhat picturesque, it does not detract from the heartfelt intimacy he experienced, not only with the written poem, but with its performative power. "Feeling the meaning" and "being sure of its effect" thus become the mantra of the ideal translator, one able to grasp viscerally the sense and spirit of the work, and one who knows how to convey it with full confidence in how it is going to be received by the audience. Whether or not Carlyle was able to do so in his own translation does not detract from this spontaneous outburst of affection towards the actual people who, with their impromptu recitations, enriched his emotional understanding of the poem and of its impact.

C. H. Sisson reminisces about the soothing presence of the Inferno, of all Cantiche, during the turbulent times he spent in the British ranks in India during the early 1940s: "The volume containing the Inferno was one of the three little books I took with me when I went overseas in the army, and although my Heine seemed more accessible at that time the luminosity of a few lines of Dante, pecked at here and there, settled invincibly in my mind at this restless period" (Sisson i-ii). Although not overtly stated, translation emerges here almost as a natural or therapeutic search for the comfort afforded by the source text in troubled phases of one's life, and even as an attempt to offer that same comfort to others. Other translators also discuss their intimate connection with the Commedia, to which they are drawn in different but equally powerful ways. For W. S. Merwin, similarly as for Carlyle, it is through its sound:

Other moments in the Purgatorio had held me repeatedly. Almost thirty years earlier, on the tube in London, I had been reading canto 5 , which was already familiar ground. It was like listening to a much-loved piece of music, hearing a whole current in it that had never before seemed so clear. I rode three stops past my destination and had to get off and go back and be late. And here once again, trying vainly to find equivalents for words and phrases, I was in the grip of the Purgatorio. (Merwin xiii-xiv)

The aching thrill of being held captive by an enthralling literary or philosophical masterpiece is only surpassed by the added challenge of translating it. Its echo then becomes a haunting companion, and its images heighten one's senses, as in the case of Dorothy Sayers, who describes the experience in terms akin to rapture:

The whole of the Middle Ages moves before us in Dante's thumbnail sketches: the shipbuilders in the Venice Arsenal, the cooks and scullions 'prodding the stew' with long forks, the labourer resting on the hillside of an 
evening and watching the fireflies flickering down the valley, the shepherd despairing at the long-continued frost, the peasant-girl pursued into dreamland by her daily task of gleaning, the overworked ostler hurrying to get his horses groomed, the Romans inventing a system of traffic-control for the handling of holiday crowds, green logs sizzling on the hearth, a night alarm of fire and the mother fleeing naked with her child clutched in her arms, beggars in the street and the savage watchdogs rushing out upon them, the sounds and smells of a medieval hospital; the pleasures of hawking, hunting, bathing, gambling; the bustle of tilt and tournament, the noise and vicissitudes of war. (Sayers 65)

Through the act of translation the translator's world morphs into Dante's and Dante's into the translator's, infusing one with renewed life and enriching the other with new meaning, as happens to Ciaran Carson:

The deeper I got into the Inferno, the more I walked. Hunting for a rhyme, trying to construe a turn of phrase, l'd leave the desk and take to the road, lines ravelling and unravelling in my mind. Usually l'd head for the old Belfast Waterworks, a few hundred yards away from where I live. The north end of the Waterworks happens to lie on one of Belfast's sectarian fault lines. Situated on a rise above the embankment is the Westland housing estate, a Loyalist enclave which, by a squint of the imagination, you can see as an Italian hill-town. Flags proclaim its allegiance. A gable wall bears the letters UFF- Ulster Freedom Fighters - flanked by two roundels, each bearing a Red Hand within a white Star of David on a blue ground. Often a British Army helicopter eye-in-the-sky is stationed overhead. As I write, I can hear its ratchety interference in the distance; and, not for the first time, I imagine being airborne in the helicopter, like Dante riding on the flying monster Geryon, looking down into the darkness of that place in Hell called Malebolge. 'Rings of ditches, moats, trenches, fosses / military barriers on every side': I see a map of North Belfast, its no-go zones and tattered flags, the blackened side-streets, cul-de-sacs and bits of wasteland stitched together by dividing walls and fences. For all the blank abandoned spaces it feels claustrophobic, cramped and medieval. Not as beautiful as Florence, perhaps, but then Florence is 'the most damned of Italian cities, wherein there is place neither to sit, stand, or walk,' according to Ezra Pound. And we see again the vendetta-stricken courtyards and surveillance towers of Dante's birthplace, where everyone is watching everyone, and there is little room for manoeuvre. (Carson xi-xii)

Dante's inferno doesn't disappear into the jaws of a hellish Belfast, and Belfast doesn't put on an improbable medieval robe. Rather, the two evoke each other, call to each other, neither one losing its individuality —and it is precisely in that space where the ideal translation resides. 
One might object that these invasions of the personal sphere play no role whatsoever in assessing the quality of a translation and that they constitute neither authoritative guides to the source text (like for instance critical introductions) nor pieces of creative non-fiction, because the translator's preface still needs to fulfill the requirements of its genre. However, the value of these intrusions lies precisely in their resistance to the guidelines and expectations of the genre, since they demand to be considered independently of any practical function, and they offer no guarantee with regard to the value of the translation or to the translator's competence. In "Persuasive Spaces: Translators' Prefaces to the Divine Comedy" I posited them as "democratic spaces of individuality," but a valid counter-argument to that definition is that their all-toocommon absence-casual or forced by publishing restrictions-does not make them enough of a staple of translated texts to be considered truly "democratic". Still, precisely because they are among the rare sites where translators have the opportunity to take the stage and discuss their relationship to and agency on the text in their own terms, in highlighting some of these unexpected findings this essay seeks to promote further research on paratext in the field of translation, and to encourage, on the part of translators, a more experimental use of this treasured locus of visibility.

\section{Works Cited}

Biancolli, Louis. Translator's Note. The Divine Comedy: Paradise, by Dante Alighieri, Washington Square Press, 1966, pp. xx-xx.

Carlyle, John A. Preface. Dante's Divine Comedy, by Dante Alighieri, Harper \& Brothers, 1849, pp. iii-viii.

Carson, Ciaran. Acknowledgements and Introduction. The Inferno of Dante Alighieri, by Dante Alighieri, Granta Books, 2002, pp. ix-xxi.

Dimitriu, Rodica. "Translators' Prefaces as Documentary Sources for Translation Studies." Perspectives - Studies in Translatology, vol. 17, no.3, 2009, pp. 193-206.

Famula, Christine. "Translators' Prefaces in Canadian Literary Texts." Beyond Comparison - Au-delà des Comparaisons. Proceedings of the $5^{\text {th }}$ Annual Comparative Canadian Literature Conference, 2004, Université de Sherbrooke, edited by Roxanne Rimstead, Michelle Ariss, Simon Gilbert and Suzanne O'Connor, Les Éditions Topeda Hill, 2005.

Feltrin-Morris, Marella. "Persuasive Spaces: Translators' Prefaces to the Divine Comedy." Forum Italicum, vol. 50, no. 1, 2016, pp. 38-49.

Friederich, Werner Paul. Dante's Fame Abroad 1350-1850. Edizioni di Storia e di Letteratura, 1950.

Genette, Gérard G. Paratexts: Thresholds of interpretation. Translated by Jane E. Lewin, Cambridge University Press, 1997.

Hartama-Heinonen, Ritva. "Translators' Prefaces - A Key to the Translation?" Folia Translatologica, no. 4, 1995, pp. 33-42.

Havely, Nick. Dante's British Public. Oxford University Press, 2014.

Langdon, Courtney. Preface. The Divine Comedy of Dante Alighieri: Inferno, by Dante Alighieri, Harvard University Press, 1918, pp. viii-xvii. 
McRae, Ellen. "The Role of Translators' Prefaces to Contemporary Literary Translations into English." Dissertation, University of Auckland, 2010.

Merwin, W. S. Foreword. Purgatorio, by Dante Alighieri, Alfred A. Knopf, 2000, pp. viixxix.

Oktar, Lütfiye and Neslihan Kansu-Yetkiner. "Different Times, Different Themes in Lady Chatterley's Lover: A Diachronic Critical Discourse Analysis of Translator's Prefaces." Neohelicon, no. 39, 2012, pp. 337-364.

Paloposki Outi. "The Translator's Footprints." Translators' Agency, edited by Tuija Kinnunen and Kaisa Koskinen, Tampere University Press, 2010, pp. 86-107.

Peabody, J. C. Preface. Dante's Hell: Cantos I to X, Ticknor \& Fields, 1857, p. vii.

Sayers, Dorothy Leigh. Introduction. The Comedy of Dante Alighieri: Hell by Dante Alighieri, Penguin Books, 1949, pp. 9-66.

Sisson, Charles Hubert. On Translating Dante. The Divine Comedy, by Dante Alighieri, Carcanet New Press, Ltd., 1980, pp. i-ix.

Toledano Buendía, Carmen. "Listening to the Voice of the Translator: a Description of Translator's Notes as Paratextual Elements." Dissertation, University of La Laguna, 2013.

Volpi, Odoardo. Preface. The Comedy of Dante Alighieri, by Dante Alighieri, Wakeman, 1836, pp. v-xxxiii. 